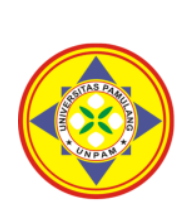

\title{
PENGARUH QUICK RATIO DAN LONG TERM DEBT TO EQUITY RATIO TERHADAP HARGA SAHAM PADA PT. WASKITA KARYA TbK PERIODE 2012-2019
}

\author{
${ }^{1 *}$ Yulian Bayu Ganar, 2 Putri Kusmiyati \\ Universitas Pamulang, Tangerang Selatan, Banten, Indonesia \\ *yubaga29@gmail.com
}

\begin{abstract}
Abstrak
Penelitian ini bertujuan untuk mengetahui pengaruh variabel Quick Ratio dan Long Term Debt to Equity Ratio terhadap Harga Saham. Jenis penelitian ini adalah kuantitatif. Data yang diolah berupa laporan keuangan PT. Waskita Karya Tbk periode 2012 sampai dengan periode 2019. Hasil Penelitian ini menunjukan bahwa Quick Ratio (QR), Long Term Debt to Equity Ratio (LTDtER) secara simultan berpengaruh terhadap Harga Saham. Secara parsial menunjukkan bahwa Quick Ratio mempunyai pengaruh negatif terhadap Harga Saham sedangkan Long Term Debt to Equity Ratio tidak berpangaruh terhadap Harga Saham pada PT. Waskita Karya Tbk. Untuk mendapatkan data keuangan tersebut penulis mengunjungi website PT.Waskita Karya Tbk dan Bursa Efek Indonesia (IDX).

Kata Kunci : Quick Ratio (QR), Long Term Debt to Equity Ratio (LTDtER) dan Harga Saham

Abstract

This study aims to determine the effect of the variable Quick Ratio and Long Term Debt to Equity Ratio on stock prices. This type of research is quantitative. The data processed in the form of financial statements of PT. Waskita Karya Tbk for the period 2012 to 2019. The results of this study indicate that the Quick Ratio (QR), Long Term Debt to Equity Ratio (LTDtER) simultaneously affect stock prices. Partially shows that the Quick Ratio has a negative effect on the Stock Price while the Long Term Debt to Equity Ratio has no effect on the Stock Price at PT. Waskita Karya Tbk. To get the financial data, the writer visited the website of PT. Waskita Karya Tbk and the Indonesia Stock Exchange (IDX).
\end{abstract}

Keywords : Quick Ratio (QR), Long Term Debt to Equity Ratio (LTDtER) and Stock Price

\section{PENDAHULUAN}

Bertambahnya jumlah perusahaan baru dari hari ke hari membuat persaingan dunia bisnis di Indonesia menjadi semakin ketat persaingannya. Terdapat perusahaan-perusahaan yang bergerak dibidang kontruksi, jasa, manufaktur, maupun dagang yang saling bersaing untuk dapat bertahan dan menjadi yang terbaik. Hal tersebut adalah untuk mendorong perusahaan agar terus melakukan strategi yang baik untuk menghindari kerugian.

PT. Waskita Karya adalah Badan Usaha Milik Negara Indonesia yang bergerak dibidang konstruksi. BUMN ini didirikan pada tanggal 1 Januari 1961, bercikal bakal dari sebuah perusahaan Belanda bernama "Volker Aannemings
Maatschappij N.V.", yang diambil alih berdasarkan Keputusan No.62 Pemerintah Tahun 1961.

Salah satu konsep dalam manajemen keuangan bahwa tujuan yang ingin dicapai adalah memaksimalisasi nilai perusahaan. Tujuan tersebut dicapai dengan memaksimalisasi nilai pasar pada harga saham yang bersangkutan. Harga saham merupakan nilai sekarang dari arus kas yang akan diterima oleh pemilik saham dikemudian hari. Harga saham akan mencerminkan kinerja suatu perusahaan bila kinerja perusahaan buruk biasanya harga saham akan turun. Sebaliknya, jika kinerja perusahaan membaik maka harga saham akan naik. 
Tabel 1. Nilai Saham PT. Waskita Karya Tbk. Periode 2012-2019

\begin{tabular}{|c|c|}
\hline Tahun & Harga Saham (Rp) \\
\hline 2012 & 439 \\
\hline 2013 & 395 \\
\hline 2014 & 1,433 \\
\hline 2015 & 1,670 \\
\hline 2016 & 2,550 \\
\hline 2017 & 2,210 \\
\hline 2018 & 1,680 \\
\hline 2019 & 1,485 \\
\hline
\end{tabular}

Sumber : Dunia Investasi

Di dalam pasar modal harga saham dapat naik ataupun turun. Perkembangan harga saham selain di pengaruhi faktor makro ekonomi yang berada diluar perusahaan, juga dipengaruhi oleh faktor mikro ekonomi. Faktor mikro ekonomi merupakan faktor yang berada di dalam perusahaan, antara lain ditunjukkan oleh rasio keuangan perusahaan seperti Quick Ratio (QR), Long Term Debt to Equity Ratio (LTDtER), dan lain-lainnya. Segala aktivitas yang dilakukan perusahaan tidak hanya serta merta tanpa penilaian dan diuji, tetapi perlu adanya pertanggungjawaban dalam bentuk laporan keuangan. Pemilik suatu usaha akan mengetahui kondisi keuangan dan kemajuan serta kinerja usahanya dari laporan keuangan.

Quick Ratio, rasio keuangan ini digunakan ketika dalam suatu perushaaningin mengukur kemampuan perusahaannya dalam memenuhi kewajibannya untuk jangka pendek. Pemenuhan kewajiban tersebut dilakukan dengan menggunakan asset perusahaan yang bersifat liquid (asset berwujud). Rasio ini merupakan perbandingan antara aset, persediaan dan hutang. Nilai Quick Ratio yang baik adalah bernilai 1 maka semakin baik posisi keuangan perusahaan tersebut.

Tabel 2. Nilai Quick Ratio

PT. Waskita Karya Tbk. Periode 2012-2019

\begin{tabular}{|c|c|}
\hline Tahun & QR (kali) \\
\hline 2012 & 1.39 \\
\hline 2013 & 1.38 \\
\hline 2014 & 1.28 \\
\hline 2015 & 1.26 \\
\hline 2016 & 1.09 \\
\hline 2017 & 0.94 \\
\hline
\end{tabular}

\begin{tabular}{|l|l|}
\hline 2018 & 1.09 \\
\hline 2019 & 0.99 \\
\hline
\end{tabular}

Sumber : Laporan keuangan akhir tahun PT.

Waskita Karya Tbk

Berdasarkan data dan hasil tabel 2 tersebut, menunjukkan bahwa Quick Ratio pada PT. Waskita Karya Tbk, dalam 8 tahun terakhir berturut-turut megalami fluktuasi terjadi penurunan dari tahun 2012 sampai tahun 2017, mengalami kenaikan pada tahun 2018, dan mengalami penurunan tahun 2019.

Long Term Debt to Equity Ratio, rasio ini digunakan untuk mengukur berapa bagian dari setiap rupiah modal sendiri yang dijadikan jaminan hutang jangka panjang. Rasio ini merupakan perbandingan antara hutang jangka panjang dan modal. Dengan demikian besarnya hutang jangka panjang membawa pengaruh besar pada net profit margin. Hal ini menyebabkan hak para pemegang saham akan berkurang dan akan berpengaruh terhadap minat investor yang juga akan mempengaruhi harga saham yang semakin menurun.

Tabel 3.Nilai Long Term Debt to Equity Ratio

PT. Waskita Karya Tbk. Periode 2012-2019

\begin{tabular}{|c|c|}
\hline Tahun & LTDtER (\%) \\
\hline 2012 & 0.53 \\
\hline 2013 & 0.41 \\
\hline 2014 & 0.69 \\
\hline 2015 & 0.72 \\
\hline 2016 & 0.79 \\
\hline 2017 & 1.00 \\
\hline 2018 & 1.34 \\
\hline 2019 & 1.66 \\
\hline
\end{tabular}

Sumber : Laporan keuangan akhir tahun PT.

Waskita Karya Tbk - Website Perusahaan.

Selanjutnya dapat disimpulkan bahwa Long Term Debt to Equity Ratio cenderung mengalami kenaikkan tiap tahunnya, dapat dilihat kenaikkan rasio LTDtER ditunjukkan dari tahun 2012 sampai tahun 2013 mengalami penurunan, dan pada tahun 2014 sampai dengan 2019 mengalami kenaikan. Maka dapat dikatakan PT. Waskita Karya Tbk mengalami kenaikan juga penurunan hutang atau kewajiban yang ditanggung oleh perusahaan. Berdasarkan penjelasan yang telah disampaikan maka semakin 
tinggi Quick Ratio suatu perusahaan maka bisa dikatakan perusahaan tersebut baik dan cepat dalam melunasi hutang lancarnya.

Dengan seperti itu akan membuat para investor tertarik untuk berinvestasi. Sebaliknya, ketika Long Term Debt to Equity Ratio menunjukkan angka yang rendah, berarti investor akan merasa aman untuk menanamkan modalnya dan imbasnya adalah dapat menarik minat investor karena harga saham perusahaan pun dapat naik. Maka dalam kesempatan ini peneliti tertarik untuk meneliti variabel yang mempengaruhi Harga Saham PT. Waskita Karya Tbk.

Dimana peneliti mengamati ketika Quick Ratio dan Long Term Debt to Equity Ratio mengalami fluktuasi diikuti juga dengan perubahan Harga Saham. Atas dasar pertimbangan tersebut maka peneliti tertarik untuk mengambil judul "Pengaruh Quick Ratio dan Long Term Debt to Equity Ratio terhadap Harga Saham pada PT. Waskita Karya Tbk Periode 2012-2019". TINJAUAN PUSTAKA

1. Pengertian Manajemen

$$
\text { Menurut Wijayanto }
$$

Manajemen yaitu "Ilmu dan seni, yang terdiri atas perencanaan, pengorganisasian, pengarahan, dan pengawasan terhadap kinerja organisasi dengan menggunakan sumber daya yang dimiliki untuk mencapai tujuan dan sasaran organisasi"

2. Pengertian Manajemen Keuangan

$$
\text { Menurut Sartono dalam }
$$

Kamaluddin (2017:248) "Sebagai manajemen dana baik yang kaitan dengan pengalokasian dana dalam berbagai bentuk investasi secara efektif maupun usaha pengumpulan dana untuk pembiayaan investasi atau pembelanjaan secara efesien". Sedangkan menurut (Brigham \& Houston) dalam Nurwita (2020:4) "Seni dan ilmu untuk me-manage uang yang meliputi proses, institusi atau lembaga, pasar dan instrumen yang terlibat dengan masalah transfer uang diantara individu, bisnis dan pemerintah".
3. Laporan Keuangan

Menurut Kasmir dalam Septiana (2019:3) “Laporan yang menunjukan kondisi keuangan perusahaan pada saat ini atau pada suatu periode tertentu.

4. Likuiditas

Menurut Fred Weston dalam Kasmir (2017:129) "Rasio likuiditas (liquidity ratio) merupakan rasio yang menggambarkan kemampuan perusahaan dalam memenuhi kewajiban (utang) jangka pendek" Artinya apabila perusahaan ditagih, perusahaan akan mampu untuk memenuhi utang tersebut.

5. Harga Saham

Harga Saham menurut Ayu dan Edy Handoyo dalam Darmawan (2016:88) adalah "Harga yang terkandung dalam surat kepemilikan bagian modal berdasarkan penilaian pasar yang dipengaruhi oleh permintaan dan penawaran di bursa efek".

6. Solvabilitas

Menurut Kasmir (2017:151) Rasio solvabilitas atau leverage ratio merupakan rasio yeng digunakan untuk mengukur sejauh mana aktiva perusahaan dibiayai dengan utang. Artinya berapa besar beban utang yang ditanggung perusahaan dibandingkan dengan aktivanya.

\section{METODE}

Penelitian ini menggunakan data kuantitatif yaitu data yang berbentuk angka dan mengacu pada perhitungan dengan data-data yang berasal dari laporan tahunan PT. Waskita Karya periode 2012-2019. Dalam penelitian ini Variabel yang igunakan adalah Quick Ratio dan Long Term Dent to Equity Ratio dan Harga Saham. Populasi dalam penelitian ini adalah laporan keuangan PT. Waskita Karya Tbk. Sample dalam penelitian ini adalah laporan keuangan perusahaan berupa neraca dan laporan laba rugi pada PT. Waskita Karya Tbk periode 2012-2019. 
Teknik pengumpulan data yang digunakan adalah Analisis Statistik Deskriptif, Analisis Regresi Linear Sederhana, Analisis Regresi Linier
Berganda, Uji Asumsi Klasik, Hipotesis, Uji Koefisien Korelasi dan Uji Koefisien Determinasi (R2).

\section{HASIL DAN PEMBAHASAN}

\section{Analisis Statistik Deskriptif}

Tabel 4. Hasil Uji Statistik Deskriptif

Descriptive Statistics

\begin{tabular}{|l|l|l|l|l|l|}
\hline & $\mathrm{N}$ & Minimum & Maximum & Mean & Std. Deviation \\
\hline Quick Ratio & 8 & 0.94 & 1.39 & 1.1775 & 0.17335 \\
\hline $\begin{array}{l}\text { Long Term Debt to } \\
\text { Equity Ratio }\end{array}$ & 8 & 0.41 & 1.66 & 0.8925 & 0.42196 \\
\hline Harga Saham & 8 & 395 & 2550 & 1482.75 & 757.532 \\
\hline Valid N (listwise) & 8 & & & & \\
\hline
\end{tabular}

Sumber : Output SPSS

Berdasarkan data diatas menunjukkan bahwa $\mathrm{N}$ atau jumlah data setiap variabel yang valid berjumlah 8, dari 8 data sampel Harga Saham (Y), nilai minimum sebesar Rp. 395, nilai maksimum Rp. 2550, nilai mean sebesar Rp. 1482,75, dan nilai standar deviasi sebesar Rp. 757,532

Quick Ratio $\left(\mathrm{X}_{1}\right)$ nilai minimum sebesar 0,94, nilai maksimum sebesar 1,39 , nilai mean sebesar 1,1775 , dan nilai standar deviasi sebesar 0,17335.

Long Term Debt to Equity Ratio $\left(\mathrm{X}_{2}\right)$ nilai minimum sebesar 0,41 , nilai maksimum sebesar 1,66, nilai mean sebesar 0,8925, dan nilai standar deviasi sebesar 0,42196.

\section{Analisis Regresi Linear Berganda}

Menurut Hendri (15:12) Analisis regresi linear berganda bertujuan untuk menguji hubungan antara satu variabel dengan variabel lain. Varibel yang dipengaruhi disebut variabel tergantung atau dependen, sedangkan variabel yang mempengaruhi disebut variabel bebas atau variabel independen

Rumus regresi linear berganda yaitu :

$$
Y=\alpha+\beta 1 X 1+\beta 2 X 2+e
$$

Tabel 5. Hasil Uji Analisis Regresi Linier Berganda

Coefficients $^{\mathrm{a}}$

\begin{tabular}{|c|c|c|c|c|c|c|}
\hline \multirow{2}{*}{\multicolumn{2}{|c|}{ Model }} & \multicolumn{2}{|c|}{$\begin{array}{l}\text { Unstandardized } \\
\text { Coefficients }\end{array}$} & \multirow{2}{*}{$\begin{array}{l}\text { Standardized } \\
\text { Coefficients } \\
\text { Beta } \\
\end{array}$} & \multirow[b]{2}{*}{$\mathrm{T}$} & \multirow[b]{2}{*}{ Sig. } \\
\hline & & B & Std. Error & & & \\
\hline \multirow[t]{3}{*}{1} & (Constant) & 8692.583 & 2568.709 & & 3.384 & 0.020 \\
\hline & Quick Ratio & -5360.133 & 1723.711 & -1.227 & -3.110 & 0.027 \\
\hline & $\begin{array}{l}\text { Long Term Debt } \\
\text { to Equity Ratio }\end{array}$ & -1006.471 & 708.134 & -0.561 & -1.421 & 0.214 \\
\hline
\end{tabular}

a. Dependent Variable: Harga Saham

Harga Saham $=8692,583-5360,133 \times 1-$ $1006,471 \times 2$

a. Konstanta (a) adalah sebesar 8692,583

Artinya, jika Quick Ratio dan Long Term Debt to Equity Ratio bernilai (0) maka Harga Saham adalah 8692,583 b. Nilai koefisien regresi variabel Quick Ratio bernilai negatif yaitu sebesar 5360,133 .

Artinya bahwa variabel Quick Ratio memiliki pengaruh negatif terhadap harga saham. Bila variabel Quick Ratio sebesar 1 satuan, maka akan menurunkan Harga Saham sebesar 5360,133 satuan dengan 
asumsi variabel independen lain nilainya tetap.

c. Nilai koefisien regresi variabel Long Term Debt to Equity Ratio bernilai negatif yaitu sebesar $-1006,471$.

Artinya bahwa variabel Long Term Debt to Equity Ratio memiliki pengaruh negatif terhadap terhadap Harga Saham. Bila variabel Long Term Debt to Equity Ratio sebesar 1 satuan, maka akan menurunkan Harga Saham sebesar 1006,471 satuan dengan asumsi variabel independen lain nailainya tetap.

\section{Uji Hipotesis}

\section{a. Pengujian Hipotesis Secara Parsial} (Uji t)

Menurut Ghozali (2018:98) Uji satatistik $t$ pada dasarnya menunjukan seberapa jauh pengaruh satu variabel penjelas/independent secara parsial individual dalam menerangkan variasi variabel dependen.

Menurut Ghozali dalam Sari (2018:48) Uji $\mathrm{t}$ dilakukan untuk membadingkan $t_{\text {hitung }}$ dan $t_{\text {tabel }}$ dengan ketentuan sebagai berikut :

1) Ho diterima dan $H_{a}$ ditolak jika

$$
t_{\text {hitung }}<t_{\text {tabel }} a=0,05
$$

2) Ho ditolak dan $H_{a}$ diterima jika

$t_{\text {hitung }}>t_{\text {tabel }} a=0,05$

Adapun rumus untuk mencari $t_{\text {tabel }}$ yaitu :

- $\mathrm{t}$ tabel $=\mathrm{a} / 2 ; \mathrm{n}$ (jumlah sampel yang digunakan - $\mathrm{k}$ (jumlah variabel independent - 1

- $\mathrm{t}$ tabel $=0,05 / 2 ; 8-2-1$

- $\mathrm{t}$ tabel $=0,025 ; 5$

Maka diperoleh $t_{\text {tabel }}$ sebesar $=$ 2,571 . Berikut ini hasil uji $t$ dengan menggunakan pengujian statistik SPSS (Statistical Product and Service Solutions).

Tabel 6. Hasil Uji t

Coefficients $^{\mathrm{a}}$

\begin{tabular}{|c|c|c|c|c|c|c|}
\hline \multirow{2}{*}{\multicolumn{2}{|c|}{ Model }} & \multicolumn{2}{|c|}{$\begin{array}{l}\text { Unstandardized } \\
\text { Coefficients }\end{array}$} & \multirow{2}{*}{$\begin{array}{l}\text { Standardized } \\
\text { Coefficients } \\
\text { Beta }\end{array}$} & \multirow[b]{2}{*}{$\mathrm{T}$} & \multirow{3}{*}{$\frac{\text { Sig. }}{0.020}$} \\
\hline & & $\mathrm{B}$ & Std. Error & & & \\
\hline \multirow[t]{3}{*}{1} & (Constant) & 8692.583 & 2568.709 & & 3.384 & \\
\hline & Quick Ratio & -5360.133 & 1723.711 & -1.227 & -3.110 & 0.027 \\
\hline & $\begin{array}{l}\text { Long Term Debt } \\
\text { to Equity Ratio }\end{array}$ & -1006.471 & 708.134 & -0.561 & -1.421 & 0.214 \\
\hline
\end{tabular}

a. Dependent Variable: Harga Saham

Hasil uji t antara variabel Quick Ratio terhadap variabel Harga Saham menunjukkan nilai $t_{\text {hitung }}$ sebesar 3,110 dengan nilai signifikansi sebesar 0,027 yang artinya angka ini lebih kecil dari tingkat signifikansi 0,05 atau $(0,027<0,05)$, derajat kebebasan $t_{\text {tabel }}$ sebesar 2,571 dan dengan malakukan perbandingan yaitu $t_{\text {hitung }}(-3,110)>t_{\text {tabel }}(2,571)$ sehingga dapat disimpulkan bahwa $\mathrm{H}_{0}$ ditolak dan $\mathrm{H}_{\mathrm{a}}$ terima yang artinya bahwa Quick Ratio secara parsial berpengaruh negatif (-) terhadap Harga Saham.

Selanjutnya hasil uji $\mathrm{t}$ antara Long Term Debt to Equity Ratio terhadap Harga Saham

menunjukkan nilai $t_{\text {hitung }}$ sebesar 1,421 dengan nilai signifikansi sebesar 0,214 yang artinya angka ini lebih besar dari tingkat signifikansi 0,05 atau $(0,214>0,05)$, derajat kebasan $t_{\text {tabel }}$ sebesar 2,571 dan dengan melakukan perbandingan yaitu $t_{\text {hitung }}(-1,421)<t_{\text {tabel }}(2,571)$ sehingga dapat disimpulkan bahwa $\mathrm{H}_{0}$ diterima dan $\mathrm{H}_{\mathrm{a}}$ ditolak yang artinya bahwa Long Term Debt to Equity Ratio secara parsial tidak berpengaruh terhadap Harga Saham.

\section{b. Pengujian Hipotesis Secara Simultan (Uji F)}

Menurut Ghozali dalam Sari (2018:48) Uji statistik F pada 
dasarnya menunjukkan apakah semua variabel independen atau bebas yang dimasukkan dalam model mempunyai pengaruh secara bersama-sama terhadap variabel dependen/terikat.

Menurut Ghozali dalam Sari (2018:48) Uji f dilakukan dengan membandingkan signifikansi $F_{\text {hitung }}$ dengan $F_{\text {tabel }}$ dengan ketentuan sebagai berikut :

1) Ho diterima dan $\mathrm{H}_{a}$ ditolak jika

$F_{\text {hitung }}<\mathrm{F}_{\text {tabel }} \mathrm{a}=0,05$

2) Ho ditolak dan $\mathrm{H}_{\mathrm{a}}$ diterima jika

$\mathrm{F}_{\text {hitung }}>\mathrm{F}_{\text {tabel }} \mathrm{a}=0,05$
Adapun rumus untuk mencari $\mathrm{F}_{\text {tabel }}$ yaitu :

- Tingkat signifikansi $=5 \%$ atau 0,05

- $\quad \mathrm{F}$ tabel $=\mathrm{k}$ (jumlah variabel independen) ; n (jumlah sampel yang digunakan - $\mathrm{k}$ (jumlah variabel independen)

- $\mathrm{F}$ tabel $=2 ; 8-2$

- $\mathrm{F}$ tabel $=2 ; 6$

Maka diperoleh $F_{\text {tabel }}$ pada penelitian ini sebesar $=5,14$. Berikut ini hasil uji $\mathrm{F}$ dengan menggunakan pengujian statistik SPSS (Statistical Product and Service Solutions).

Tabel 7. Hasil Uji F

ANOVAa

\begin{tabular}{|l|l|l|l|l|l|l|}
\hline \multicolumn{2}{|l|}{ Model } & Sum of Squares & Df & Mean Square & F & Sig. \\
\hline \multirow{3}{*}{1} & Regression & 2889365.733 & 2 & 1444682.866 & 6.406 & $.042^{\mathrm{b}}$ \\
\cline { 2 - 8 } & Residual & 1127613.767 & 5 & 225522.753 & & \\
\cline { 2 - 8 } & Total & 4016979.500 & 7 & & & \\
\hline
\end{tabular}

a. Dependent Variable: Harga Saham

b. Predictors: (Constant), Long Term Debt to Equity Ratio, Quick Ratio

Sumber: Output SPSS

Berdasarkan hasil pengujian Analysis Of Variance (ANOVA) pada tabel 4.14 diperoleh nilai Fhitung sebesar 6,406 dengan nilai signifikansi 0,042 , yang artinya nilai signifikansi lebih kecil dari $a=0,05$ atau $(0,042<0,05)$, sedangkan $F_{\text {tebel }}$ sebesar 5,14. Dengan kondisi ini dimana $F_{\text {hitung }}$ lebih besar dari pada $\mathrm{F}_{\text {tabel }}(6,406>5,14)$ maka dapat disimpulkan bahwa $\mathrm{H}_{0}$ ditolak dan $\mathrm{H}_{\mathrm{a}}$ diterima yang artinya bahwa Quick Ratio dan Long Term Debt to Equity Ratio secara bersama-sama berpengaruh positif dan signifikan terhadap Harga Saham.

\section{Uji Koefisien Korelasi}

Menurut Sugiyono dalam Munadjat (2019:68) Koefisien Korelasi "Angka yang menunjukan arah dan kuatnya hubungan antara dua variabel atau lebih". Koefisien korelasi dapat digunakan untuk mengukur atau mengetahui pengaruh Quick Ratio dan Long Term Debt to Equity Ratio terhadap Harga Saham.

Nilai koefisien korekasi paling kecil 1 dan paling besar 1 . Jadi jika $r=$ koefisien korelasi, maka nilai $\mathrm{r}$ dapat dinyatakan sebagai berikut : $1 \leq 1 \geq 1$.

Tabel 8. Hasil Uji Koefisien Korelasi Parsial

\section{Correlations}

\begin{tabular}{l|l|l} 
Harga & Quick & Long Term Debt to
\end{tabular}

Saham Ratio Equity Ratio

\begin{tabular}{|l|l|l|l|l|}
\hline \multirow{3}{*}{$\begin{array}{l}\text { Pearson } \\
\text { Correlation }\end{array}$} & Harga Saham & 1.000 & -0.778 & 0.420 \\
\cline { 2 - 5 } & Quick Ratio & -0.778 & 1.000 & -0.799 \\
\cline { 2 - 5 } & $\begin{array}{l}\text { Long Term Debt to } \\
\text { Equity Ratio }\end{array}$ & 0.420 & -0.799 & 1.000 \\
\hline \multirow{2}{*}{ Sig. (1-tailed) } & Harga Saham & & 0.011 & 0.150 \\
\cline { 2 - 5 } & Quick Ratio & 0.011 & & 0.009 \\
\hline
\end{tabular}




\begin{tabular}{|l|l|l|l|l|}
\hline \multirow{2}{*}{$\mathrm{N}$} & $\begin{array}{l}\text { Long Term Debt to } \\
\text { Equity Ratio }\end{array}$ & 0.150 & 0.009 & \\
\hline & Harga Saham & 8 & 8 & 8 \\
\cline { 2 - 6 } & Quick Ratio & 8 & 8 & 8 \\
\cline { 2 - 5 } & $\begin{array}{l}\text { Long Term Debt to } \\
\text { Equity Ratio }\end{array}$ & 8 & 8 & 8 \\
\hline
\end{tabular}

a. Korelasi parsial Quick Ratio dengan Harga Saham

Hasil perhitungan korelasi parsial Quick Ratio dapat dinilai koefisien negatif sebesar 0,778. Maka dapat disumpulkan bahwa Quick Ratio dengan Harga Saham memiliki hubungan negatif dan Kuat. Sesuai dengan tabel interprestasi koefisien korelasi 0,60-0,799 mempunyai hubungan yang Kuat.

b. Korelasi parsial Long Term Debt to Equity Ratio dengan Harga Saham
Hasil perhitungan korelasi parsial Long Term Debt to Equity Ratio dapat dinilai koefisien positif 0,420. Maka dapat disimpulkan bahwa Long Term Debt to Equity Ratio dengan Harga Saham memiliki hubungan positif dan Sedang. Sesuai dengan tabel interprestasi koefisien korelasi 0,40-0,599 mempunyai hubungan yang Sedang.

Korelasi Simultan Quick Ratio dan Long Term Debt to Equity Ratio terhadap Harga Saham.

Tabel 9. Hasil Uji Koefisien Korelasi Simultan

Model Summaryb

\section{Uji Koefisien Determinasi}

\begin{tabular}{|c|c|c|c|c|}
\hline Model & $\mathrm{R}$ & R Square & $\begin{array}{l}\text { Adjusted R } \\
\text { Square }\end{array}$ & $\begin{array}{l}\text { Std. Error } \\
\text { of the } \\
\text { Estimate }\end{array}$ \\
\hline 1 & $.848^{a}$ & 0.719 & 0.607 & 474.892 \\
\hline
\end{tabular}

a. Predictors: (Constant), Long Term Debt to Equity Ratio, Quick Ratio

b. Dependent Variable: Harga Saham

Sumber: Output SPSS

Uji Koefisen Determinasi (KD) adalah angka atau indeks yang digunakan untuk mengetahui besarnya sumbangan pengaruh Quick Ratio dan Long Term Debt to Equity Ratio terhadap Harga Saham. Nilai koefisien determinasi dapat dilihat pada tabel Model Summary pada kolom $R$ square. Nilai yang tertera selanjutnya diubah ke dalam bentuk persen (dengan dikali $100 \%$ ). Berikut ini data pada tabel model Summary tabel 10.

Tabel 10. Hasil Uji Koefisien Determinasi

Model Summary ${ }^{b}$

\begin{tabular}{|l|l|l|l|l|}
\hline Model & R & R Square & Adjusted R Square & Std. Error of the Estimate \\
\hline 1 & $.848^{\mathrm{a}}$ & 0.719 & 0.607 & 474.892 \\
\hline
\end{tabular}

a. Predictors: (Constant), Long Term Debt to Equity Ratio, Quick Ratio

Berdasarkan tabel 10. Model Summary di atas besarnya nilai pengaruh varibel bebas ditunjukan oleh nilai $\mathrm{R}^{2}=0,719$, maka $\left(\mathrm{KD}=\mathrm{r}^{2} \times 100 \%=\right.$ $0,719 \times 100 \%=71,90 \%$ jadi dapat disimpulkan bahwa Quick Ratio dan Long Term Debt to Equity Ratio berpengaruh sebesar 71,90\% terhadap Harga Saham, sedangkan 28,10\% dipengaruhi oleh variabel lain yang tidak diteliti di dalam penelitian ini.

\section{KESIMPULAN DAN SARAN Kesimpulan}

Berdasarkan uraian pada bab-bab sebelumnya, dan dari hasil analisis serta pembahasan mengenai pengaruh Quick Ratio (QR) dan Long Term Debt to Equity Ratio (LTDtER) terhadap Harga Saham 
pada PT. Waskita Karya Tbk Periode 20122019, maka diperoleh kesimpulan sebagai berikut :

1. Quick Ratio secara parsial berpengaruh negatif (-) terhadap Harga Saham dengan uji hipotesis diperoleh nilai $t_{\text {hitung }}$ sebesar -3,110 dengan nilai signifikansi sebesar 0,027 yang artinya angka ini lebih kecil dari tingkat signifikansi 0,05 atau $(0,027<0,05)$, derajat kebebasan $t_{\text {tabel }}$ sebesar 2,571 dan dengan malakukan perbandingan yaitu $t_{\text {hitung }}(-3,110)>t_{\text {tabel }}$ $(2,571)$ sehingga dapat disimpulkan bahwa $\mathrm{H}_{0}$ ditolak dan $\mathrm{H}_{\mathrm{a}}$ yang artinya bahwa Quick Ratio secara parsial berpengaruh negatif (-) terhadap Harga Saham.

2. Long Term Debt to Equity Ratio secara parsial tidak berpengaruh terhadap Harga Saham dengan uji hipotesis diperoleh nilai thitung sebesar $-1,421$ dengan nilai signifikansi sebesar 0,214 yang artinya angka ini lebih besar dari tingkat signifikansi 0,05 atau $(0,214>$ $0,05)$, derajat kebasan $t_{\text {tabel }}$ sebesar 2,571 dan dengan melakukan perbandingan yaitu $t_{\text {hitung }}(-1,421)<t_{\text {tabel }}(2,571)$ sehingga dapat disimpulkan bahwa $\mathrm{H}_{0}$ diterima dan $\mathrm{H}_{\mathrm{a}}$ yang artinya bahwa Long Term Debt to Equity Ratio secara parsial tidak berpengaruh terhadap Harga Saham.

Quick Ratio dan Long Tern Debt to Equity Ratio terhadap Harga Saham dengan uji hipotesis di peroleh nilai $F_{\text {hitung }}$ sebesar 6,406 dengan nilai signifikansi 0,042, yang artinya nilai signifikansi lebih kecil dari $\alpha=$ 0,05 atau $(0,042<0,05)$, sedangkan $F_{\text {tebel }}$ sebesar 5,14. Dengan kondisi ini dimana $F_{\text {hitung }}$ lebih besar dari pada $F_{\text {tabel }}(6,406>$ $5,14)$ maka dapat disimpulkan bahwa $\mathrm{H}_{0}$ ditolak dan $\mathrm{H}_{\mathrm{a}}$ diterima yang artinya bahwa Quick Ratio dan Long Term Debt to Equity Ratio secara bersama-sama berpengaruh positif dan signifikan terhadap Harga Saham.

\section{Saran}

Berdasarkan kesimpulan dan dari hasil penelitian mengenai pengaruh Quick Ratio (QR) dan Long Term Debt to Equity Ratio (LTDtER) terhadap Harga Saham PT.
Waskita Karya Tbk. Periode 2012-2019 maka peneliti memberikan saran sebagai berikut :

1. Bagi Investor

Variabel yang tidak memiliki pengaruh signifikan terhadap Harga Saham secara parsial adalah Long Term Debt to Equity Ratio. Dengan demikian variabel tersebut kurang mampu digunakan oleh pihak manajemen maupun invetor untuk memprediksi pengaruh Harga Saham pada PT. Waskita Karya Tbk. dan diharapkan investor mempertimbangkan pada saat melakukan keputusan investasi.

2. Bagi Perusahaan

Bagi perusahaan sebaiknya selalu memperhatikan Long Term Debt to Equity Ratio, karena sesuai dengan penelitian ini variabel tersebut menjadi acuan bagi investor untuk berinvestasi. Selanjutnya, perusahaan tetap berupaya mengelola keuangan perusahaan dengan baik. Karena dengan menerapkan pengelolaan dana kreditur dengan baik, maka perusahaan mencerminkan kinerja yang baik. Sehingga akan memberikan respon positif bagi investor untuk membeli saham

3. Untuk Peneliti Selanjutnya

a. Melakukan kajian lebih lanjut dengan memasukan variabel bebas lainnya untuk mengehatui pengaruhnya terhadap Harga Saham.

b. Jangka waktu penelitian dapat diperpanjang dan dengan jumlah sampel perusahaan yang lebih besar. Perpanjangan periode penelitian dan pembahasan jumlah sampel agar memberikan hasil yang lebih baik.

\section{DAFTAR PUSTAKA}

Aisyah, S., Febrianty., Siswai, I, B, A, D, H., Jony., Supitriyani., Astuti., Jatiningrum, C, I, A., \& Yuniningsih. (2020). Manajemen Keuangan. Jakarta: Yayasan Kita Menulis.

Darmawan A. (2016). Pengaruh Rasio Likuiditas, Solvabilitas dan 
Profitabilitas Terhadap Harga Saham. Jurnal Stei Ekonomi, 25(1)

Ghozali, I. (2018). Aplikasi Analisis Multivariate Dengan Program IBM SPSS 25 Edisi 9. Semarang: Undip

Hendri, E. (2015). Pengaruh Debtto Asset Ratio (Dar), Long Term Debt To Equity Ratio (LTDER) Dan Net Profit Margin (NPM) terhadap Harga Saham Pada Perusahan Perbankan yang Terdaftar Di Bursa Efek Indonesia. Jurnal Media Wahana Ekonomika, 12(2).

Kamaluddin, A. (2017). Administrasi Bisnis. Makasar: CV SAH MEDIA.

Kasmir. (2017). Analisis Laporan Keuangan. Jakarta: PT. RAJAGAFINDO PERSADA

Lutfi, A. M., Erlangga, H., Nurjaya, N., Priadana, S., \& Dwiwarman, D. A. (2021). Pengaruh Capital Adequacy Ratio Dan Bopo Ratio Terhadap Return On Asset Pada Pt. Bank Muamalat Indonesia, Tbk Periode 2010-2019. Jurnal Ekonomi Efektif, 3(3).

Najibullah, et al. (2021). Pengaruh non Performing Financing dan Financing to Deposit Ratio terhadap Pembiayaan pada Bank DKI Syariah. Jurnal Neraca Peradaban. Volume 1. Issue1. Pages 48-5

Nurjaya, et al (2021). Pengaruh Liquiditas dan Profitabilitas terhadap Return
Saham: Studi Empiris Pada Perusahaan Real Estate Dan Property Yang Terdaftar Di Bursa Efek Indonesia Tahun 2017-2019. Jurnal Tadbir Peradaban Volume 1. Issue.1. Pages 60-68.

Pujiati, H., Sunarsi, D., Affandi, A., \& Anggraeni, N. (2021). Effect of ISO 9001: 2015 Quality Management Implementation in Education on School Performance. Journal of Contemporary Issues in Business and Government, 27(1), 1848-1855.

Salam, A., Hikmat, I., Haquei, F., \& Badariah, E. (2021). The Influence of Share Ownership, Funding Decisions, Csr and Financial Performance of Food Industry. Annals of the Romanian Society for Cell Biology, 12698-12710.

Sari, W. P. (2018). Pengaruh Rasio Keuangan terhadap Harga Saham Pada Perusahaan Manufaktur Go Public yang Terdaftar di Bursa Efek Indonesia. Jurnal Ilmiah Skylandsea, 4352.

Septiana, A. (2019). Analisis Laporan Keuangan Konsep Dasar dan Deskripsi Laporan Keuangan. Jakarta: DUTA MEDIA PUB LISHING

Sugiyono. (2017). Statistik Untuk Penelitian. Bandung : CV. ALFABETA. 